\title{
The use of comparative law in the practice of the Hungarian Constitutional Court: An empirical analysis (1990-2019)
}

\author{
ESZTER BODNÁR*
}

Premium postdoctoral scholar, Hungarian Academy of Sciences, ELTE Eötvös Loránd University, Hungary

\section{ORIGINAL RESEARCH PAPER}

Received: October 7, 2020 • Accepted: November 27, 2020

Published online: June 8, 2021

(c) 2021 The Author(s)

\section{ABSTRACT}

Courts conducting constitutional review do not work as 'ivory towers' any longer: they are part of the global dialogue on constitutional ideas and thoughts. This dialogue includes an exchange of experiences with fellow constitutional and apex courts, as well as the close observation of developments in foreign constitutional and legal systems, scholarship, and international trends. The Constitutional Court of Hungary has been an active participant in this dialogue since the Court's establishment in 1989, albeit with varying levels of intensity and goals. Moving beyond the often anecdotal observations in this field, the paper aims to conduct a deep analysis of how the Court uses comparative law in its work (during the preparatory phase and the drafting of final decisions) and examines the factors that may influence the Court's practice in this area. Such a clear overview can assist proponents of the use of comparative reasoning to contravene the increasing amount of criticism of the practice's legitimacy and selectivity.

\section{KEYWORDS}

constitutional courts, comparative law, international judicial dialogue

\footnotetext{
*Corresponding author. E-mail: eszter.bodnar@ajk.elte.hu
} 


\section{INTRODUCTION}

Courts conducting constitutional review do not work as 'ivory towers' any longer: they are part of the global dialogue on constitutional ideas and thoughts. This dialogue includes an exchange of experiences with fellow constitutional and apex courts, as well as the close observation of developments in foreign constitutional and legal systems, scholarship and international trends.

The Constitutional Court of Hungary has been an active participant in this dialogue since the Court's establishment in 1989, albeit with varying levels of intensity and goals. Moving beyond the often anecdotal observations in this field, this paper aims to conduct a deep analysis of how the Court uses comparative law in its work (during the preparatory phase and the drafting of final decisions) and examines the factors that may influence the Court's practice in this area. Such a clear overview can assist proponents of the use of comparative reasoning to contravene the increasing amount of criticism of its authority and judicial selectivity.

Part 1 presents the research methodology of this project, which highlighted empirical research: specifically, case law analysis and expert interviews with justices and law clerks. The results of the research are presented in the next two parts. Part 2 provides an overview and analysis of the quantitative data: where and how the Constitutional Court cited foreign law, in what kinds of cases, which justices used the technique, how often, and other relevant data. Part 3 goes further and analyses the background factors that can influence the use of comparative law, including relevant institutional and personal features. Part 4 describes and reflects on the two main criticisms of the Court's practice in this area (its legitimacy and methodology), while the concluding remarks in Part 5 suggest ways to improve the practice in general.

\section{RESEARCH METHODOLOGY}

Understanding the use of comparative law in the practice of the Hungarian Constitutional Court requires a complex approach that combines different kinds of empirical research methods. This paper is based on research results stemming from two main sources: case law analysis and expert interviews, covering the thirty years of the Court's existence. These features differentiate the paper from previous works that used only citation analysis and spanned a shorter time period, ${ }^{1}$ focused exclusively on a certain field of practice, ${ }^{2}$ used only citations of foreign case law ${ }^{3}$ or worked with all types of reasoning, not just comparative. ${ }^{4}$ The case law analysis can only flag where the Court acknowledged the foreign source of its inspiration by providing a citation or other identifying information. However, there are also cases where foreign jurisprudence was used without attribution. Interviews can help to reveal these hidden comparative imports. ${ }^{5}$

The aim of the research was to find all cases where the Court referred to foreign law, including citations to specific regulations, case law or general references. The paper focuses only

\footnotetext{
${ }^{1}$ E.g. 1999-2008 in Szente (2010); 1999-2010 in Szente (2013b).

${ }^{2}$ E.g. only family law cases Bodnár (2020).

${ }^{3}$ E.g. Szente (2013b).

${ }^{4}$ E.g. Jakab and Fröhlich (2017).

${ }^{5}$ Or at least some of them. Even with this option, the influence of foreign materials is certainly underestimated.
} 
on horizontal communication (citing foreign law), ${ }^{6}$ and therefore it does not include references to international and supranational documents or case law. ${ }^{7}$

The case law research covered the period between 1 January 1990 (when the Constitutional Court started its work) and 31 December 2019. This means that a period of thirty years of practice was examined, including the so-called 'formative period' of domestic jurisprudence, ${ }^{8}$ which also provided an opportunity to analyse long-term tendencies.

For the analysis, I used the public online database available on the web page of the Court. ${ }^{9}$ The database includes all of the Court's decisions, regardless of the decision-making configuration (in plenary or panels) or where the case opinion was published. I conducted a series of searches to find every mention of foreign authorities in the texts of the decisions. The search terms included the names of all countries of the world and their adjectival forms (e.g. German, English), all continent names and general references such as 'European countries' and 'developed Western nations'. After the search was concluded, each individual case was screened, and all false positives (instances where country names appeared in the case for other reasons) were excluded.

At the end of the process, each decision was analysed and coded to create a data set that featured 246 cases. All relevant decisions were tagged with related data that was publicly available. This related data included the date of the decision, the location of the citation (unanimous, majority, concurring or dissenting opinion), the name of the justice who authored the opinion, the Court's competence in the case and the topic of the dispute. Data on the citations was also added, including the cited jurisdiction, the type of citation (general or specific) and the subject of the citation (regulation, case or fact).

Additionally, I approached via email fourteen current and former justices of the Hungarian Constitutional Court, along with seventeen current and former law clerks. I tried to cover the entire history of the Court and to conduct interviews with law clerks who worked with different justices. Most of them answered very quickly and were willing to participate; only a few did not answer or rejected my interview invitation. Between May and September 2020, I conducted twenty-four interviews: ten with justices and fourteen with law clerks. ${ }^{10}$ The justices were in office between 1998 and today, and the former law clerks worked at the Court between 1990 and today, so their collective experience covered a long period of time.

\footnotetext{
${ }^{6}$ See Anne-Marie Slaughter's categorization of horizontal communication, vertical communication and mixed verticalhorizontal communication in Slaughter (1994) 103-11.

${ }^{7}$ While there are similarities between the use of comparative law and international/supranational law in constitutional adjudication, and the latter can also demonstrate the openness of a court towards transnational engagement, there are several differences that are essential and justify a separate analysis.

${ }^{8}$ Some authors argue that a study on the frequency of foreign citations should avoid the uncommonly high number of references to foreign jurisprudence expected during the so-called 'formative period' of domestic jurisprudence, as it is a potentially anomalous phase [e.g. Roy (2004) 119]. However, I decided to include all of the Court's case law in the analysis in order to better understand its longitudinal tendencies to use comparative law.

${ }^{9}<$ https://alkotmanybirosag.hu/ugykereso> accessed 2 October 2020. The database is in Hungarian. There is also an English-language database of the decisions, but its content is limited.

${ }^{10} \mathrm{I}$ am extremely grateful to the justices and law clerks who were generous with their time and helped me with this research by sharing their insights.
} 
Before the interviews, I researched the selected justices by reading their biographies, published academic articles and books, speech transcripts, and any other books and articles written about their work and lives. I also checked the number of decisions each justice had penned, as well as their reasoning in those opinions. In the instance of the law clerks, I researched both them and the justices they had served. If the clerks were now professors, I also reviewed their publications with an eye on their proclivity for the use of comparative law in their research. While these thorough investigations helped to prepare the right questions for the interviews, they also helped to double-check the information that the interviewees shared with me.

The interviews were originally planned to be approximately $45 \mathrm{~min}$ long, but they actually lasted between thirty and ninety minutes. In most instances, due to the COVID-19 pandemic, the interviews were conducted online and were primarily administered with the use of video. Some of the interviews took place in the current offices of the interviewees and in coffeehouses. All of the interviews were conducted in Hungarian.

To ensure trust, the interviews were not recorded; only notes were taken. The interviews were anonymous, and the information collected was not attributed. Some of the interviewees expressed their appreciation for the anonymity.

All of the interviews were held in a relaxed atmosphere, and the interviewees were helpful and open. It is also important to emphasize that, from the interviews, it became clear that most of the interviewees (but not all) were favourable to judicial internationalization, and that fact may have contributed to their openness. ${ }^{11}$

The interviews were in-depth and semi-structured, focussing on the interviewees' experiences and working methods at the Court, their professional and personal backgrounds, how these backgrounds related to the use of comparative law and their opinions on the use of comparative law in constitutional adjudication.

Notes taken during the interviews were typed out on the same day or the following day. The data derived from the interviews was cross-checked with the results of the case law analysis and the research conducted on the publications and public speeches of the justices and law clerks.

\section{QUANTITATIVE DATA ON THE USE OF COMPARATIVE LAW AT THE HUNGARIAN CONSTITUTIONAL COURT}

Courts addressing constitutional issues around the world use comparative law in varying degrees. While some courts frequently cite foreign constitutions, statutes or case law (e.g. the Supreme Court of Canada, the High Court of Australia and the Supreme Court of Ireland), others refer to foreign law only sporadically (e.g. the German Federal Constitutional Court) or almost never (e.g. the Supreme Court of the United States). ${ }^{12}$ The Hungarian Constitutional Court falls somewhere in the middle of this scale.

Between the years 1990 and 2019, the Court issued 9,766 decisions. Among these decisions, 246 contained at least one reference to foreign law in either the majority or minority opinion. This means that comparative law played a role in only $2.5 \%$ of the cases. As seen in Fig. 1 , the

\footnotetext{
${ }^{11}$ See Mak (2015) 63.

${ }^{12}$ Groppi and Ponthoreau (2013) 3.
} 


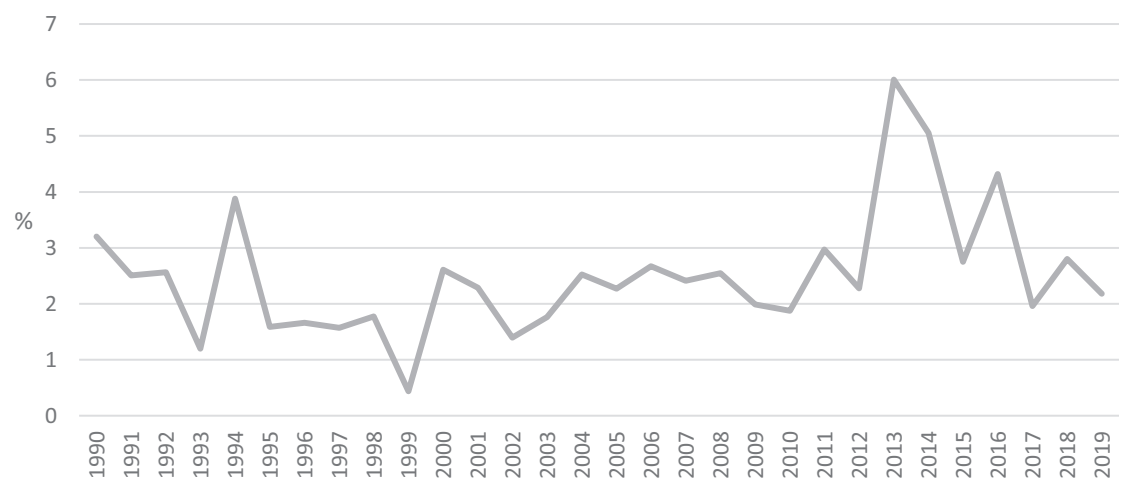

Fig. 1. Ratio of cases with forgein citation

annual percentages of decisions containing at least one foreign citation range between $0.4 \%$ (1999) and 6\% (2013). ${ }^{13}$

There were foreign citations in majority, concurring and dissenting opinions. Foreign references appeared most often in majority opinions (99 in total) and dissenting opinions (90 in total), and a bit less often in unanimous opinions (52 in total) and concurring opinions (64 in total).

According to the data, the Constitutional Court cited foreign law in decisions issued in almost every competence. ${ }^{14}$ There was also an example of the use of foreign citations in a constitutional complaint case involving electoral law, where the procedure required an extremely short deadline. ${ }^{15}$ Figure 2 shows the percentage of cases with foreign citations after 2012, broken down by competence. ${ }^{16}$ As illustrated, foreign law was most often cited in more abstract and impactful competences, such as in the abstract interpretation of the Fundamental Law, ${ }^{17}$ and in abstract constitutional review procedures (both ex ante and ex post). ${ }^{18}$

The data on the number of foreign citations per decision reveals significant differences. There were, for example, cases where the Court mentioned only one foreign jurisdiction, ${ }^{19}$ but there were others that cited more than fifteen to twenty foreign jurisdictions; these latter decisions usually compiled information on the regulatory systems of different countries. ${ }^{20}$ In the

\footnotetext{
${ }^{13}$ Naturally, the number of cases where foreign law was considered but not cited, especially during the first phase of the Court's operation, may be much higher. See Dupré (2003).

${ }^{14}$ There are no foreign references in decisions issued in competences that are concrete rather than abstract: Opinion on the Dissolution of a Local Representative Body Operating Contrary to the Fundamental Law (Act CLI of 2011 on the Constitutional Court [CC Act], Section 34), Resolving Conflicts of Competence (CC Act, Section 36).

${ }^{15}$ 3093/2018. (III. 26.) CC decision.

${ }^{16}$ Figure 2 contains only the cases decided after 2012, as the competences of the Constitutional Court were significantly amended by the new constitution and Constitutional Court Act that entered into force on 1 January 2012.

${ }^{17} \mathrm{CC}$ Act, Section 38.

${ }^{18} \mathrm{CC}$ Act, Sections 23 and 24.

${ }^{19}$ E.g. only the decision of the German Federal Constitutional Court is mentioned in the 3375/2018. (XII. 5.) CC decision.

${ }^{20}$ E.g. the 3191/2019. (VII. 16.) CC decision presents the models of judicial review in the public procurement procedures of eighteen countries; the 54/2004. (XII. 13.) CC decision [ABH 2004, 690] provides an overview of the regulation of marijuana use in countries from every continent.
} 


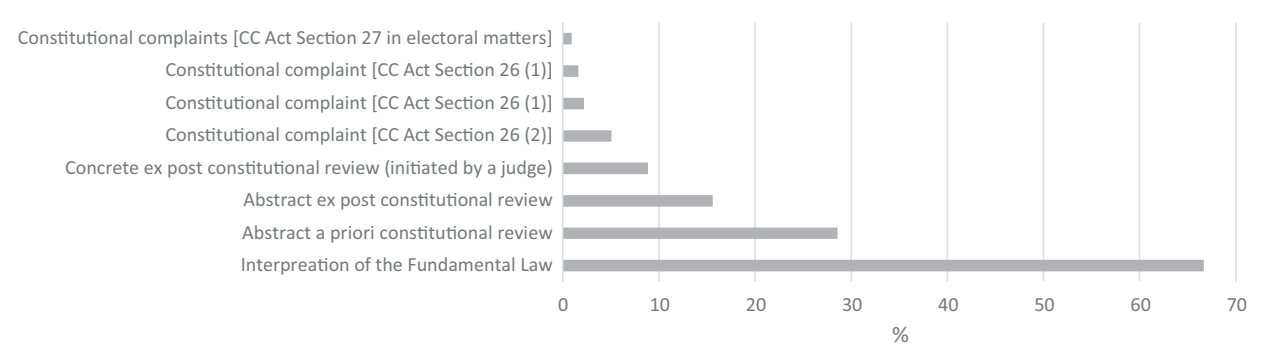

Fig. 2. Ratio of forgein citation in the different competences

decisions with a high number of foreign citations, it was usually both the majority and concurring/dissenting opinions that cited several foreign sources. Table 1 identifies the cases that contained the highest numbers of foreign references.

During the selected period, the Constitutional Court's justices used comparative reasoning in both human rights litigation (e.g. a case about freedom of expression in an electoral campaign ${ }^{21}$ ) and institutional cases (e.g. freedom of speech as it applies to members of Parliament ${ }^{22}$ ). A third type of case, which also cited foreign law regularly, involved disputes related to Hungary's membership in the European Union (EU), the application of European law and the interpretation of international agreements.

Figure 3 shows the distribution of the cited foreign jurisdictions. The number of German references stands out as the largest set, followed by references to the law of the United States. The Constitutional Court has emphasized several times that it should analyse how the 'developed democracies' handle a particular legal situation. In this context, however, the Court has only assessed the practices of the US Supreme Court and the European Court of Human Rights (ECtHR), ${ }^{23}$ with the latter representing the continental legal culture. ${ }^{24} \mathrm{Be}^{-}$ sides Germany, the most cited European jurisdictions in the study were France, Austria, the United Kingdom, Italy, Spain, Belgium, and Switzerland. These were followed by citations from Central and Eastern European countries (mainly Poland, the Czech Republic and Slovakia).

The forms and content of the citations also varied widely. The Constitutional Court often referred to a single foreign legal act, which could be a constitution, ${ }^{25}$ statute, ${ }^{26}$ provincial statute ${ }^{27}$ lower-level legal act ${ }^{28}$ or a judicial decision. Most of the cited judicial decisions were

${ }^{21} 6 / 2007$. (II. 27.) CC decision, ABH 2007, 135.

${ }^{22}$ 4/1999. (III. 31.) CC decision, ABH 1999, 52.

${ }^{23}$ E.g. 1/2019. (II. 13.) CC decision.

${ }^{24}$ Szente (2013b) 261.

${ }^{25}$ E.g. the 33/2013. (XI. 22.) CC decision cites the German and Slovenian constitutions.

${ }^{26}$ E.g. the 55/1994. (XI. 10.) CC decision [ABH 1994, 296] refers to the legislation of several German states; the 23/2014. (VII. 15.) CC decision cites a statute of the US state of Washington.

${ }^{27}$ E.g. the 16/2013. (VI. 20.) CC decision cites the Swiss Criminal Code.

${ }^{28}$ E.g. the 12/2006. (IV. 24.) CC decision (ABH 2006, 234) cites the standing order of the Austrian National Council. 
Table 1. Decisions with the most foreign citations in the year

\begin{tabular}{|c|c|c|c|}
\hline Year & Decision & Number of citations & Topic \\
\hline 1990 & 23/1990. (X. 31.) CC decision & 4 & abolition of death penalty \\
\hline 1991 & 15/1991. (IV. 13.) CC decision & 17 & establishment of a new village \\
\hline 1992 & 9/1992. (I. 30.) CC decision & 4 & review by public prosecutors \\
\hline 1993 & 10/1993. (II. 27.) CC decision & 3 & religious holidays \\
\hline 1994 & 60/1994. (XII. 24.) CC decision & 5 & personal data of people in public life \\
\hline 1995 & 67/1995. (XII. 7.) CC decision & 2 & sanctioning without trial \\
\hline 1996 & 800/B/1993. CC decision & 2 & liquidation procedure \\
\hline 1997 & 4/1997. (I. 22.) CC decision & 4 & $\begin{array}{l}\text { constitutional review of international } \\
\text { agreements }\end{array}$ \\
\hline 1998 & 48/1998. (XI. 23.) CC decision & 7 & abortion \\
\hline 1999 & 4/1999. (III. 31.) CC decision & 8 & continuity of the Parliament's operation \\
\hline 2000 & 13/2000. (V. 12.) CC decision & 8 & protection of national symbols \\
\hline 2001 & 58/2001. (XII. 7.) CC decision & 12 & right for a name \\
\hline 2002 & 37/2002. (IX. 4.) CC decision & 5 & sanctioning of same-sex relationships \\
\hline 2003 & 22/2003. (IV. 28.) CC decision & 9 & euthanasia \\
\hline 2004 & 54/2004. (XII. 13.) CC decision & 35 & crimes concerning drugs \\
\hline 2005 & 43/2005. (XI. 14.) CC decision & 17 & sterilization \\
\hline 2006 & 88/B/1999. CC decision & 23 & right to strike \\
\hline 2007 & 77/2007. (X. 31.) CC decision & 11 & referendum on the introduction of siesta \\
\hline 2008 & 154/2008. (XII. 17.) CC decision & 16 & same-sex registered relationship \\
\hline 2009 & 97/2009. (X. 16.) CC decision & 10 & administration of the justice system \\
\hline 2010 & 32/2010. (III. 25.) CC decision & 25 & same-sex registered relationship \\
\hline 2011 & 61/2011. (VII. 13.) CC decision & 20 & $\begin{array}{l}\text { constitutional review of constitutional } \\
\text { amendments }\end{array}$ \\
\hline 2012 & 33/2012. (VII. 17.) CC decision & 14 & retirement of judges \\
\hline 2013 & 14/2013. (VI. 17.) CC decision & 31 & investment agreements \\
\hline 2014 & 36/2014. (XII. 18.) CC decision & 11 & right to remedy \\
\hline 2015 & 28/2015. (IX. 24.) CC decision & 5 & referendum on the retirement age \\
\hline 2016 & 22/2016. (XII. 5.) CC decision & 19 & collective expulsion \\
\hline 2017 & 3076/2017. (IV. 28.) CC decision & 10 & bailiffs \\
\hline 2018 & 6/2018. (VI. 27.) CC decision & 6 & name of transsexual persons \\
\hline 2019 & 3191/2019. (VII. 16.) CC decision & 18 & public procurement procedure \\
\hline
\end{tabular}




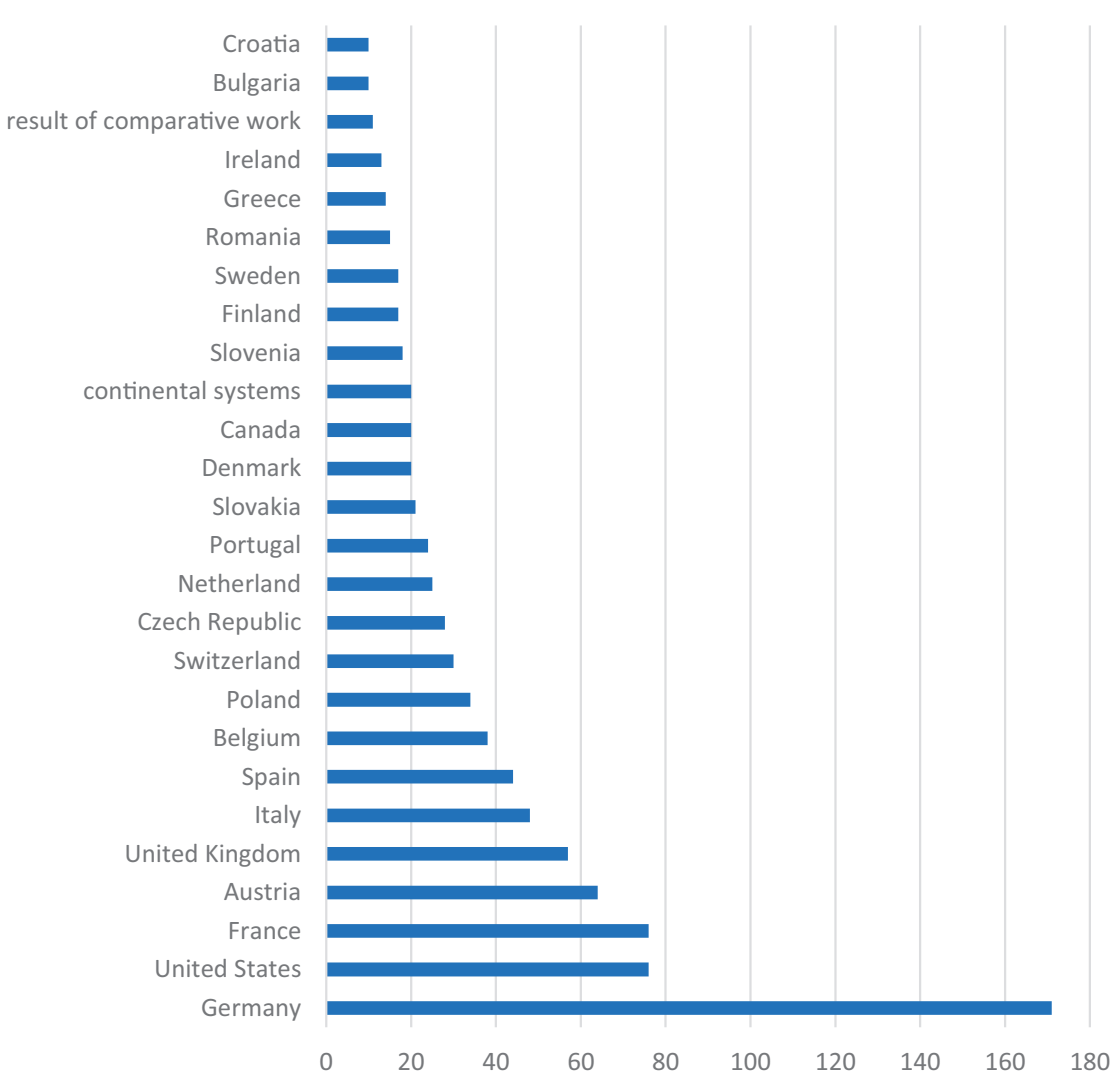

Fig. 3. Number of opinions with citation of a jurisdiction

issued by courts addressing constitutional cases (constitutional court, ${ }^{29}$ apex court ${ }^{30}$ or constitutional council ${ }^{31}$ ), but there were also apex court opinions issued in non-constitutional cases, ${ }^{32}$ as well as decisions of lower-level courts. ${ }^{33}$ In some instances, a concurring or separate opinion of a foreign decision was cited. ${ }^{34}$ The Constitutional Court often 'borrowed' a comparative analysis from an international institution; for example, it based its reasoning on the

${ }^{29}$ E.g. the 22/2016. (XII. 5.) CC decision cites the opinion of the Constitutional Court of the Czech Republic no. ÚS 50/04, 8 March 2006.

${ }^{30}$ E.g. the 23/2014. (VII. 15.) CC decision cites the US Supreme Court decisions Ewing v. California, 538 U.S. 11 (2003) and Lockyer v. Andrade, 538 U.S. 63 (2003).

${ }^{31}$ E.g. the 3/2019. (III. 7.) CC decision cites decision no. 2018/717-718 of the French Conseil constitutionnel.

${ }^{32}$ E.g. the 22/2003. (IV. 28.) CC decision (ABH 2003, 235) cites the decision of the German Bundesgerichtshof BGHSt 42 , 305.

${ }^{33}$ E.g. the 3076/2017. (IV. 28.) CC decision cites the decision of the Canadian Court of Appeal for Ontario, no. C38295., 2003.

${ }^{34}$ E.g. the concurring opinion of Justice Kiss to the 3046/2016. (III. 22.) CC decision. 
materials of the Venice Commission, ${ }^{35}$ the comparative work of the $\mathrm{ECtHR}^{36}$ and the survey of the Council of Europe's Commission for the Efficiency of Justice (CEPEJ). ${ }^{37}$

The remaining group of citations was more general and more reference-like. First, these references often did not cite a specific legal act or case, but instead referred generally to the regulations of a given country ${ }^{38}$ or the practice of a given court. ${ }^{39}$ Second, in some cases, these references contoured part of the Court's reasoning without citing any analysed countries specifically, but rather collectively-for example, 'in several European countries', ${ }^{40}$ 'in the majority of the European countries', ${ }^{41}$ 'in the majority of European systems ${ }^{42}$ and 'in the legal system of the majority of the democratic countries' ${ }^{43}$ Third, the Court's comparative arguments sometimes referred only generally to a constitutional dogmatic term, ${ }^{44}$ a trend in constitutional history ${ }^{45}$ or even only to a societal fact. ${ }^{46}$

It is also noteworthy that the justices' overall willingness to refer to foreign law in their opinions differed. According to the study's data, there have only been four justices in the Constitutional Court who have never used foreign law citations in their decisions (some of them were in office only for a few months). Comparing the number of authored opinions to the years spent in office during the examined period (see Fig. 4$)^{47}$ reveals that Justices Pokol, Sulyok, Bragyova, Kovács, Kukorelli, Sólyom, Lévay and Holló cited foreign law the most often during the selected period.

\section{FACTORS INFLUENCING THE USE OF COMPARATIVE LAW IN THE PRACTICE OF THE HUNGARIAN CONSTITUTIONAL COURT}

Examining the empirical data on the Court's case law elicits questions about why the justices use (or do not use) foreign material, how they decide which cases to utilize for comparative analysis and how they decide which jurisdictions' laws to involve. This part of the paper, which is based on the case law database's additional data and the conducted interviews, identifies factors that can influence the use of comparative law, including both institutional and individual features. ${ }^{48}$

\footnotetext{
${ }^{35}$ E.g. 3093/2018. (III. 26.) CC decision; the concurring opinion of Justice Kiss to the 3024/2016. (II. 23.) CC decision.

${ }^{36}$ E.g. the dissenting opinion of Justice Czine to the 3146/2016. (VII. 22.) CC decision.

${ }^{37}$ E.g. 3076/2017. (IV. 28.) CC decision.

${ }^{38}$ E.g. 36/2013. (XII. 5.) CC decision.

${ }^{39}$ Pl. 61/2011. (VII. 13.) CC decision, $\mathrm{ABH} 2011,290$.

${ }^{40}$ 64/1991. (XII. 17.) CC decision, ABH 1991, 297.

${ }^{41} 28 / 2014$. (IX. 29.) CC decision.

${ }^{42}$ 21/1996. (V. 17.) CC decision, ABH 1996, 74.

4338/1993. (VI. 11.) CC decision, $\mathrm{ABH} 1993,256$.

${ }^{44}$ E.g. 'clear and present danger' in the 30/1992. (V. 26.) CC decision, ABH 1992, 167.

${ }^{45}$ E.g. the concurring opinion of Justice Pokol to the 22/2019. (VII. 5.) CC decision refers to European and American constitutional development.

${ }^{46}$ E.g. about the increase of the number of cell phones in Finland in the 18/2015. (VI. 15.) CC decision.

${ }^{47}$ In the case of joint opinions, I counted both (or all) of the justices who penned the opinion.

${ }^{48}$ About the possible factors in theory, see in detail Bodnár (2019).
} 


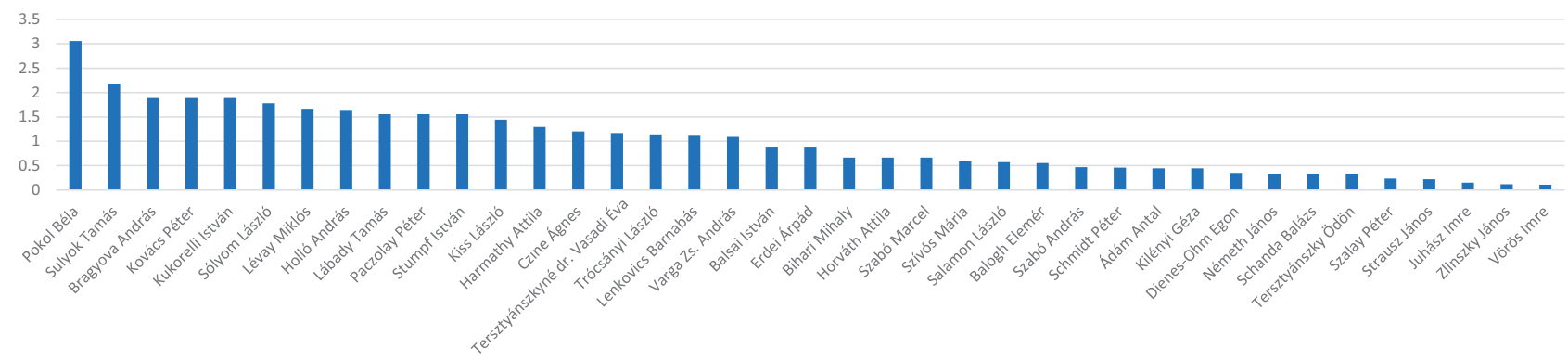

Fig. 4. Number of opinions with forgein citation per year in office 


\subsection{Effects of the constitutional and political system}

The origin and the text of the constitution have a crucial impact on the use of comparative law in constitutional interpretation. The Constitution of 1989/90 aimed to fulfil the requirements of the Western constitutional systems' rule of law, but its wording and choice of institutions also mirrored the nation's concurrent historical period, political compromises and sometimes even the inexperience or inattentiveness of the drafters themselves. ${ }^{49}$ The German constitutional system served as a model, but the Constitution also incorporated institutions borrowed from other jurisdictions (e.g. the Swedish ombudsperson).

The 1989/90 Constitution was relatively short, and consequently it provided a broad scope for interpretation. The text also used several general and vague terms, such as 'democratic Rechtsstaat' and 'right for human dignity', which invited courts to construe these terms quite liberally. ${ }^{50}$ The Constitution did not regulate methods of interpretation, so the Constitutional Court could craft its own interpretative practice, which included using the comparative method.

The adoption of a new constitution in 2011, called the Fundamental Law, provided an additional opportunity to use foreign models, ${ }^{51}$ but it also retained most of the institutions from the previous document. As a novelty, the text of the Fundamental Law includes and defines a rule of interpretation. According to Article R (3), ' $[\mathrm{t}]$ he provisions of the Fundamental Law shall be interpreted in accordance with their purposes, the National Avowal contained therein and the achievements of our historic constitution.' The text thus denotes three methods of interpretation: the teleological, the contextual connected to the Constitution's preamble and the historical. Although the Court has recognized these methods, it has not interpreted the rule as excluding other types of reasoning, such as comparative argument. Moreover, from the empirical results of this study, it is clear that the Court has relied more often on foreign citations since 2012 when this interpretive rule entered into force.

Not only is the origin of the constitutional system relevant to the use of comparative law; the history of the legal system is also pertinent to the practice. ${ }^{52}$ The different components of the Hungarian legal system have been strongly influenced by Western European jurisdictions, especially Germany, France and Austria, and in some instances, even North America. ${ }^{53}$ When reviewing the constitutionality of a statute, the Constitutional Court often looks at the origin of a given legal institution and compares its function in Hungary to that in the model country. ${ }^{54}$

Hungary's place on the world map of legal and political influences and its international connections have also a relevance. After the democratic transition from 1989 to 1990, the country took significant steps towards joining Western democracies and later the Council of Europe and the European Union (EU). According to Jackson and Tushnet, the Hungarian Constitutional Court may have held the death penalty unconstitutional in 1990 at least in part

${ }^{51}$ E.g. new fundamental rights were modelled after the Charter of Fundamental Rights of the European Union; the newly established Budgetary Council followed the Western European model.

${ }^{52}$ This is the so-called 'borrowed statute doctrine'. Annus (2004) 335.

${ }^{53}$ Harmathy (2019).

${ }^{54}$ E.g. the German, Austrian and French origins of competition law in the 34/2014. (XI. 14.) CC decision; antitrust legislation originating in Canada and the United States in the 8/2014. (III. 20.) CC decision.
} 
because Hungarian political and legal elites believed that doing so was a precondition for entry into the EU. ${ }^{55}$ Since 2010, however, the Court has started to echo several domestic political voices that urge a movement away from the Western European liberal democratic tradition, instead emphasizing the Hungarian constitutional identity ${ }^{56}$ and criticizing the EU and the ECtHR. ${ }^{57}$ In the interviews, justices and law clerks alike talked about a phenomenon where certain justices are 'allergic' to international and foreign references. As a result, some of the justices and clerks have purposefully omitted foreign references from draft decisions in order to obtain the votes of critical justices. This action naturally decreases the number of foreign citations in the Court's opinions, but it does not signify that the justices show a blanket disregard for foreign materials in their preparatory work.

Finally, the connection between the judicial system and legal scholarship is also pertinent. First, prior to 1989, in the era of socialist legal scholarship, academics could not develop their own dogmatic system. Instead, they devoted their time to the areas of comparative law or the history of law. ${ }^{58}$ When the Court first opened its doors, most of the justices came from academia, so they applied their comparative knowledge in their judicial work. While legal scholarship is rarely cited by the Court now, it is clear from the conducted interviews that the justices do use secondary scholarship when preparing their reasoning.

\subsection{Effects of the attributes of the Court}

The institutional, procedural and technical attributes of a given court can have a crucial influence on the use of comparative law in constitutional adjudication.

As constitutional review lacked a real tradition in Hungary, the Court had to craft its own process and approach and develop its case law from scratch. In the history of the Court, there are usually three recognized phases. Between 1990 and 1999, the first period, the Court began to develop its case law, and the decade was dominated by the activist approach of the Court's first president, László Sólyom. Since the Court could not apply its own precedents during this initial phase, the Court was more willing to seek foreign templates, even if they were not evident in the text of a decision. ${ }^{59}$ After 1999, however, the Court had established case law, and it could use its own precedents more often. In addition, the Court's presidents during this second phase were less activist, exhibiting a more positivist interpretation approach. ${ }^{60}$ Finally, after 2010 , the third phase of the Court's history, the Court underwent a crucial restructuring where its competences, composition and procedure changed significantly. ${ }^{61}$

The Court's three historical phases are clearly recognizable in the empirical data set of this study: the number of foreign citations is higher in the second phase than in the first, and the

\footnotetext{
${ }^{55}$ Jackson and Tushnet (1999) 171.

${ }^{56}$ E.g. 22/2016. (XII. 5.) CC decision.

${ }^{57}$ While the use of international and European law is outside the scope of this paper, some of the interviewees pointed out that there are debates within the Court about the role of these international and supranational sources in the Hungarian legal system, and some of these debates are even reflected in the texts of the Court's decisions.

${ }^{58}$ Jakab and Fröhlich (2017) 398.

${ }^{59}$ Jakab and Fröhlich (2017) 427.

${ }^{60}$ Halmai (1999).

${ }^{61}$ Sonnevend et al. (2015). 88-96.
} 
highest number appears in the third phase. However, caution is required, as these numbers can be misleading without acknowledging their context. First, as reflected in the initial phase, the Court was reluctant to explicitly cite comparative examples, even if it was clear that it followed a foreign model in its reasoning. As Zoltán Szente indicated, the Court imported entire legal institutions from other courts' practices, such as 'equal human dignity' and the 'living law'. ${ }^{62}$ Second, in the third phase of the Court's history, the high number of foreign citations is partly related to the large number of concurring and dissenting opinions, which reflects greater division among the justices rather than an internationally open court.

The Constitutional Court was originally created to be one of the most powerful constitutional review institutions in Europe. It had a broad range of competences-some were later annulled or transferred to other institutions-but in the first historical period, the Court focused on ex post constitutional reviews. These abstract cases provided opportunities for the Court to use more comparative examples. After 2012, the Court's focus shifted towards concrete review cases, such as constitutional complaints and ex post reviews initiated by justices in a concrete process. From the case law analysis, it is clear that the changes made to the Court's competences had a crucial influence on the overall frequency of its use of comparative law. While, as seen in Fig. 2, the percentage of cases with foreign references is quite high in the more abstract competences, it is lower in the concrete review cases and in constitutional complaint procedures. With regard to the latter, this is partially due to the fact that the Court filters the procedures and decides on the merits in only about $15-20 \%$ of its cases.

While the workload of the Court has been heavy for most of its thirty years, its initial abstract review system did not impose deadlines, and the Court was the master of its own agenda. The Court's new regulation, which went into effect in 2012, is also generous with procedural deadlines (except for a few competences that demand short deadlines, e.g. the ex ante abstract review procedure). This has resulted in some cases lasting for several years, but the longevity has consequently created a fertile ground for comparative reasoning.

The effect of the number of justices on the quantity of foreign references has seemingly been twofold. First, theoretically, an increase in the number of justices should lower the number of cases per justice, and thus there should be more time available for them to use comparative material during the preparatory stage. Second, the higher the number of justices, the higher is the probability that there will be concurring and dissenting opinions. As seen in the data, there was a significant rise in the total number of cases with foreign citations after 2010, when the number of justices on the Court increased from eleven to fifteen.

The number of concurring and dissenting opinions is clearly relevant to the Court's use of foreign law in its decisions. Almost one-third of the Court's opinions that contain foreign references are dissenting opinions. The interviewed justices agreed that these types of opinions offer an opportunity to cite the results of their own comparative work, even if the plenary Court is not open to the practice. Justice Kovács frequently used this method. ${ }^{63}$

The type of reasoning may also have an impact on the use of comparative law. In examining the reasoning practices of the Constitutional Court, Szente pointed out that, in its first twenty

\footnotetext{
${ }^{62}$ Szente (2013a) 505.

${ }^{63} \mathrm{He}$ also used this to emphasize Hungary's international law obligations. Justice Czine can be regarded as his successor in this practice.
} 
years, the Court failed to develop a uniform and consistent reasoning practice or theory. Indeed, the Court applied different interpretative methods to similar cases, which resulted in a constantly changing, eclectic practice. ${ }^{64}$ The Constitutional Court was, for a long time, divided over the role and methods of constitutional interpretation; justices were either textual positivists or activists. ${ }^{65}$ It would be expected that judicial activists, who generally favour extrajudicial arguments, would use comparative arguments more frequently. However, positivists are also willing to introduce foreign examples if they are legal sources (foreign constitutions, statutes and cases). In addition, the division is not so demarcated, and elements from the two differing approaches have been used by the same justices. ${ }^{66}$ This explains why it is hard to identify any correlation between the type of reasoning and the use of comparative law.

The Constitutional Court has no special internal unit dedicated to comparative work, but its law clerks do play an important role in comparative reasoning. From the Court's inception, each justice's work has been supported by three law clerks. Unlike in common law systems, these clerks are generally experienced legal professionals, some of them having worked at the Court for years or even decades.

The level of the law clerks' contributions to comparative reasoning is dependent on several factors. The first of these is a justice's general approach to the role of the law clerk. Some of the interviewed justices admitted relying heavily on the clerks, who conducted research and drafted opinions. Other justices insisted on drafting the decisions themselves and asked the clerks to only provide supporting research. As for comparative reasoning, in most of the cases, a justice did not provide specific instructions to the clerk about whether and how to conduct comparative research. Relatedly, the clerk's knowledge, abilities and interests also influenced the use of comparative arguments. First, most of the interviewed clerks spoke English, a majority also spoke German and some knew other languages (French, Italian or Spanish). Second, the younger clerks had almost all studied abroad, mostly in Europe (United Kingdom, France, Germany, etc.), and some even in North America. While the older generation had limited opportunities for engaging in international work during socialist times, almost all the interviewed clerks from the current generation had experiences abroad in at least one country. Third, while comparative law was missing from the curriculum at most of the universities the clerks attended as undergraduates, some of them had experience with it during their graduate studies. Fourth, the clerks' previous and parallel legal jobs also influenced the use of comparative law. Some of the clerks had an academic background and taught comparative technique in their university courses and performed comparative work in their research projects. Others worked in public service positions (at the Office of the Parliament, the ombudsperson's office and in government ministries) where the examination of foreign countries' laws was part of the job. Finally, many clerks talked about the Court's new grant opportunity that provides funding for law clerks to conduct research at a foreign court, university or research institute.

Finally, the Court's international connections can also influence the use of comparative law. The Court's first president, László Sólyom, established strong connections with fellow constitutional and supreme courts, especially from Western Europe and North America. The level of

\footnotetext{
${ }^{64}$ Szente (2013a) 497-98.

${ }^{65}$ Jakab and Fröhlich (2017) 395.

${ }^{66}$ Jakab and Fröhlich (2017) 395.
} 
participation in international dialogue has been shifting over the last three decades, but there are still regular bilateral visits and conferences at the Court. The interviewed justices and law clerks mentioned meetings with judges from Austria, Germany, the Visegrad countries and Romania. Although they found some of these encounters to be rather formal, there were sometimes discussions about judicial matters on the meeting agendas.

The Court also has an institutional connection with the Venice Commission through an appointed liaison officer, who is the Hungarian member of the Joint Council on Constitutional Justice. The Venice Commission provides a network for constitutional courts through which members can exchange experiences, share seminal decisions and seek advice from other courts. Courts may also ask the Venice Commission to draft an amicus curiae brief, although the Hungarian Constitutional Court has never taken advantage of this opportunity.

\subsection{Effects of the type of case}

The topic of the case is of utmost importance when judges decide whether to use comparative arguments. In the cases included in the study, Constitutional Court justices used comparative reasoning in both human rights and institutional cases (organisational and procedural rules of state organs).

Human rights cases using comparative reasoning included decisions about several fundamental rights, such as freedom of expression, ${ }^{67}$ the right to a fair trial, ${ }^{68}$ human dignity ${ }^{69}$ and freedom of assembly. ${ }^{70}$ The interviewees emphasized that it is much easier to apply a comparative method in human rights cases, as the 'connection seems evident', and they don't need to explain why there is a similarity among jurisdictions because of the global nature of human rights.

On the contrary, there were fewer foreign citations in cases involving institutional matters, although there are some examples (cases about political parties and their foundations' budgets ${ }^{71}$ and freedom of speech as it applies to members of Parliament ${ }^{72}$ ). In these types of cases, the comparison very often involved the different models of legislation that, according to the interviewees, can help to understand one's own institution. ${ }^{73}$

A third type of case, which also cites foreign law regularly, is dealing with the membership in the European Union, European law, or interpretation of international agreements (e.g. decision on the constitutionality of the Lisbon Treaty, ${ }^{74}$ decision on the European arrest warrant, ${ }^{75}$ decision dealing with the constitutional identity, ${ }^{76}$ decision on the interpretation of Geneva Convention $^{77}$ ).

\footnotetext{
${ }^{67}$ E.g. 95/2008. (VII. 3.) CC decision, 4/2013. (II. 21.) CC decision.

${ }^{68}$ E.g. 3024/2016. (II. 23.) CC decision, 23/2019. (VII. 18.) CC decision.

${ }^{69}$ E.g. 48/1998. (XI. 23.) CC decision, 28/2014. (IX. 29.) CC decision.

${ }^{70}$ E.g. 75/2008. (V. 29.) CC decision.

${ }^{71}$ E.g. 2179/B/1991. CC decision, 63/2008. (IV. 30.) CC decision.

724/1999. (III. 31.) CC decision, ABH 1999, 52.

${ }^{73}$ E.g. three models of the administration of courts are described in the 97/2009. (X. 16.) CC decision.

${ }^{74} 143 / 2010$. (VII. 14.) CC decision, ABH 2010, 698.

${ }^{75} 32 / 2008$. (III. 12.) CC decision, $\mathrm{ABH} 2008,325$.

${ }^{76} 22 / 2016$. (XII. 5.) CC decision.

${ }^{77} 4 / 2013$. (VI. 17.) CC decision, ABH 2013, 128.
} 
Besides the topic, the overall significance of the case also matters. The interviewees mentioned that they were more likely to seek foreign examples in cases dealing with a new legal institution, or those that attracted more attention in political, public or academic circles. On the contrary, they rarely conducted comparative research in an area where the Court already had well-established case law, or in cases with low relevance (especially those that had been rejected on formal grounds).

The type of the procedure is also relevant when using comparative material. Some of the Court's procedures can only be initiated by state institutions (e.g. involving the interpretation of the Fundamental Law and a priori constitutional review). With these types of cases, there is an expectation that more human power and time are invested than in a constitutional complaint initiated by individuals or private legal entities. The Court sometimes indicates that the comparative material it has used was originally cited by the initiating parties of the case, but not always. ${ }^{78}$ There are also opportunities for a legislator or initiating party to inform the Court about their position regarding a statute; this action can also be a source of comparative material. ${ }^{79}$ Finally, the Court can also accept amicus curiae briefs from interested parties (e.g. professors or non-governmental organisations), who usually make comparative arguments. ${ }^{80}$

While it is expected that a deadline would play a crucial role in the choice of using comparative law (or not), it is clear from the empirical results that it is just the opposite. Indeed, foreign references appeared more often in procedures with short deadlines than in those without a deadline. This can be explained, on the one hand, by the financial and resource capacity of state institutions that initiated these procedures, and on the other, by the high level of importance of these cases, which justifies a more thorough reasoning.

\subsection{The Personality and Background of the Justice}

A justice's professional background and personality can clearly influence that justice's willingness to use comparative reasoning. These factors, among others, encompass previous jobs, foreign language knowledge, foreign studies, research focus, international connections and personal characteristics. ${ }^{81}$ Even if the personal characteristics of a justice are not as crucial as in common law systems, they can influence whether that justice is a rapporteur, an author of a concurring or dissenting opinion or is the president of the Court.

The justices may have had extensive experience with comparative law in their previous jobs. Judges with academic backgrounds usually cite foreign law more often. This is true for the Constitutional Court because, as seen in the empirical results, six of the eight justices who used the largest number of foreign references were originally academics or worked at research institutes. On the contrary, justices with backgrounds as judges in lower-level courts, at the Supreme Court, as lawyers, as public servants or even as members of Parliament rank in the

\footnotetext{
${ }^{78}$ Therefore, data on the comparative material appearing in briefs requires the examination of available case documents. This work will be part of the next phase of this research project.

${ }^{79} \mathrm{CC}$ Act, Section 57 (1b). E.g. the Minister of Agriculture in the 41/1995. (VI. 17.) CC decision; the Minister of Justice in the $801 / \mathrm{B} / 2002$. CC decision.

${ }^{80}$ See two professors' amicus curiae briefs to the decision on euthanasia. The brief was published: Kis and Sajó (2003).

${ }^{81}$ Besides the interviewees, the main source of the justices' personal information was the web page of the Court, the CVs of the justices available on the internet and the book with judicial interviews Sereg (2005).
} 
bottom of the list of those who cited foreign jurisdictions. Some of the interviewed justices talked about hostility towards a so-called 'professorial constitutional adjudication', where judges without academic backgrounds criticize the writing styles of former professors, who cite more research studies and overall use a style similar to that of a scholarly article.

The foreign language facility of the justice can also play an important role. While the Court's first members included justices who, as professors, used German and other languages with confidence, there is a mixed scene in the later compositions of the Court. The majority of the interviewed justices spoke at least one foreign language (English, German or French), and some spoke two or three. However, they admitted that some colleagues had lower levels of foreign language facility. Even in these situations, however, a well-chosen law clerk could help a justice rank higher in terms of foreign materials usage.

Also influential are foreign experiences-studying, working or conducting research abroad. The original Constitutional Court included several justices who had Humboldt Foundation Research Awards and studied in Germany. ${ }^{82}$ Later, justices had experiences in France, Germany, the United Kingdom, the United States and the Court of Justice of the European Union.

While comparative constitutional law was not part of the university curriculum when many of the justices attended, some of them had comparative experience abroad or taught the topic as a professor.

Besides the institutional connections, the justices have also had personal foreign connections. Some interviewed justices mentioned their contacts with fellow constitutional or supreme court justices (e.g. from Austria, Italy, Germany and the United States). Some of them also had connections with neighbouring countries' constitutional courts-specifically, with those court members who were of Hungarian origin. Finally, the justices who were former professors had important interactions with fellow professors who could help with specific cases.

The evidential difference between civilist (dealing with private law) and public lawyers has varied throughout the three historical phases of the Court. In the first phase, civilist lawyers cited more foreign law, but in the following decades, public lawyers became the main importers of global ideas. This phenomenon can be explained historically; prior to 1989, the use of the comparative method was more acceptable in the private law area than in the more ideological public law. ${ }^{83}$

Szente wrote that some justices were the 'prisoners of their legal branch', as they were chained to their own area of law and were indifferent about crafting far-ranging comparisons that did not relate to their own fields of interest. ${ }^{84}$ While it is true that there are more foreign references in cases that match the specialized legal fields of the deciding justices (e.g. Justice Erdei's or Justice Lévay's opinions on criminal law cases), it should be noted that the Court usually makes some effort to allocate cases based on the justices' interests. Thus, the mathematical chance of a referral to foreign law in cases involving the justices' own fields is high.

\subsection{Factors influencing the choice of the selected jurisdiction}

While the previous section presented several factors that can influence whether the Court uses comparative law in constitutional adjudication (how often and in which cases), there are still others that can influence the choice of foreign law to be used.

\footnotetext{
${ }^{82}$ E.g. Justices Lábady, Sólyom and Vörös.

${ }^{83}$ Szente (2013b) 270.

${ }^{84}$ Szente (2013b) 270-71.
} 
The type of political regime of the cited foreign jurisdiction is of great importance. The judiciaries of liberal, democratic regimes cite each other. Especially at the beginning of its history, when choosing the model countries, the Constitutional Court clearly expressed its preference for a well-functioning constitutional system. Germany, France, Austria and the United States have historically been regarded as well-functioning Western countries, which are based on the respect for democracy, the rule of law and human rights. The Court's choice of these jurisdictions was originally made in tandem with Hungary's steps to become a party to the European Convention on Human Rights and a member of the EU.

Shared historical, political and constitutional events, as well as Hungary's geopolitical alliances (especially with the V4 countries and Austria), explain the relatively high number of citations from the Central and Eastern European region (mostly the Czech Republic, Poland, Romania and Slovakia). Some interviewees mentioned that they tried to focus on European countries, and especially on EU members, when making comparisons. The empirical data shows that, in the study's list of the top twenty-five most cited countries, the United States and Canada are the only non-European jurisdictions, and Switzerland is the only non-EU member.

The interviewed justices and law clerks also emphasized that they tried to avoid referencing countries where the status of the rule of law was tenuous (e.g. Poland in recent years), or countries where the legal system was unfamiliar to fellow justices (e.g. South Africa).

The Western European systems were used as models when the Hungarian Constitution was drafted, as well as important statutes in different legal fields. Jakab and Fröhlich recently pointed out that the terms 'modern constitutions' or 'general trends of Western democracies' have almost always meant Germany (even if the German solution was actually unique, it was presented as the Western constitutional solution). ${ }^{85}$

Western countries are not only regarded as historic and model countries where constitutional systems thrive; these countries also often appear in legal scholarship and legal education curriculums. Germany's top place on the list of cited foreign jurisdictions can be explained by the long and historical German orientation of the Hungarian legal profession, which is partly due to Germany's extensive scholarship system. ${ }^{86}$

The interviewees all emphasized that they considered language barriers when choosing the selected jurisdictions. Most of the interviewed justices and clerks were proficient in English, German and some of them French, so jurisdictions that publish regulations and case law in these languages had an advantage. The empirical data shows that the five most-cited jurisdictions were countries with English, German or French as official languages. Other jurisdictions' materials are only accessible when they are translated.

The interviewees also emphasized that a personal bond with a country is important. If a justice or clerk studied, conducted research or had another close association with a foreign jurisdiction, it was more likely that they used the law of that jurisdiction with more confidence.

\footnotetext{
${ }^{85}$ Jakab and Fröhlich (2017) 419.

${ }^{86}$ Jakab and Fröhlich (2017) 426.
} 


\section{CRITICISMS OF THE LEGITIMACY AND METHODOLOGY OF THE USE OF COMPARATIVE LAW}

After describing the factors that can influence the use of comparative law in the work of the Hungarian Constitutional Court, this part presents the two major criticisms of this practice, demonstrating how these criticisms are present (and evolving) in the Court's case law and in legal scholarship.

The first body of criticism concerns the legitimacy of comparative reasoning, which is based partly on the restricted power of judges and partly on the general character of constitutions. ${ }^{87}$ In Hungary, the legitimacy of comparative reasoning was unquestioned for a long period of time, both by the Court and in academic literature. However, a critical voice emerged several years ago. Specifically, Justice Pokol condemned the use of comparative law in constitutional decisionmaking for the first time in a 2013 concurring opinion. According to him, almost half of the reasoning in the associated majority decision had been based on foreign constitutions and foreign apex court decisions, positing that 'the other parts of the [Court's] reasoning excellently derive [the same] from the guarantees of Article XXVIII of the Hungarian Fundamental Law, therefore, basing the reasoning on foreign constitutions and apex court decisions is entirely unnecessary. The problem with this is not only that it makes the logic of the reasoning too difficult, but in my opinion, it violates the obligation of the Constitutional Court to base its decisions on the Hungarian Fundamental Law. If, because of the abstractness of a constitutional provision, it is necessary to introduce further normative standpoints, the justices can seek foreign solutions but this [technique] can be used only as a free value of thought, and not as a reason of the Constitutional Court decision. Therefore, in my opinion, the foreign solutions discussed in the draft decisions cannot remain in the published version of the Constitutional Court decision. ${ }^{88}$

The question of the legitimacy of comparative reasoning was introduced into the Hungarian Constitutional Court's decision-making process by this concurring opinion via the practice of the US Supreme Court ${ }^{89}$ but remained in minority until now. As aforementioned, the majority of the Court's members do use comparative arguments when drafting majority, concurring and dissenting opinions, which collectively serve as a rebuttal to the legitimacy criticisms.

The other body of criticism concerns selectivity and misuse-namely, that the justices use comparative examples when supporting their own views, but otherwise ignore them. ${ }^{90}$ This criticism has long been part of the discourse at the Constitutional Court and in academia. Justice Bragyova criticized, in a dissenting opinion in 2011, the scope of the jurisdictions used in the Court's comparison. ${ }^{91}$ Szente, in 2010 article on judicial dialogue, wrote that it is very adventitious in the practice of the Constitutional Court when, in cases where it finds it important to refer to foreign judicial decisions or practice, and it is not clear, to indicate on what authority the

\footnotetext{
${ }^{87}$ About the legitimacy question, see in detail Saunders (2011) 583-86.

${ }^{88} 33 / 2013$. (XI. 22.) CC decision, points [39]-[40].

${ }^{89}$ See the US debate in detail in Rosenfeld (2012) 43-51.

${ }^{90}$ See in detail Saunders (2006).

${ }^{91}$ Dissenting opinion to the 68/E/2004. CC decision, ABH 2011, 1422.
} 
Court depends to cite decisions or legal instruments in support of its opinion. It cannot be left unknown, when there is a comparative overview or analysis, what the grounds are for the selections made by the Court. ${ }^{, 92}$ In a 2013 article, Szente noted that the problem is multifaceted: '[The] Court has not evolved a coherent theory on a way of using foreign judicial precedents and practices. It does not have a well-established practice of doing so either. It means that there is no consensual interpretative doctrine to determine in which cases an international comparison should be given and nor do general guidelines exist for choosing the method of comparison. Finally, it is not clear either what the legitimacy is of a pure reference to foreign precedents in constitutional decision-making, that is, whether the citations themselves can be used as legitimate arguments in constitutional reasoning, or not (or, in other words, whether they can provide sufficient reason to choose a particular option among equally possible alternatives). There is no rule when and in which cases foreign precedents should be cited, as these references have no clear function in legal reasoning ${ }^{93}$. In addition, the Constitutional Court often chooses only references that support its concept or interpretation. ${ }^{94}$ In their 2013 study on the constitutional interpretation practice of the Constitutional Court, András Jakab and Johanna Fröhlich observed that the Court frequently imports contradictory solutions from different jurisdictions. For example, it combined the German concept of human dignity with that of Ronald Dworkin in the 23/1990. (X.31.) CC decision. ${ }^{95}$

\section{CONCLUDING REMARKS}

The Hungarian Constitutional Court is a participant in the international judicial dialogue. This paper has presented both quantitative and qualitative data pertaining to this dialogue, covering the last thirty years, based on an empirical method that included case law analysis and expert interviews with justices and law clerks.

The analysis of such a lengthy period (basically, the whole history of the Court) also provided an opportunity to uncover general trends and changes in the Court's practice of using comparative law. The Court's three identified historical periods display a variety of trends that can be explained by a number of organisational, procedural and personal factors.

The paper enumerated these influential factors and tested hypotheses using results from the empirical research. Some of the predictions have been proven wrong (e.g. that procedural deadlines do not have a real impact on the quantitative level of comparison). Other influences were not evident in the texts of decisions, but rather emerged from the interviews (e.g. how some of the justices' hostility towards the use of foreign law compelled the more open justices to exclude comparative arguments). In addition, several factors neutralized each other. Using the previous example, even justices who are open to comparative law (due to their academic backgrounds, foreign language knowledge and/or international experience), will sometimes refrain from the practice in order to avoid accusations of 'professorial constitutional adjudication.'

\footnotetext{
${ }^{92}$ Szente (2010) 61-62.

${ }^{93}$ Szente (2013b) 270-71.

${ }^{94}$ Szente (2013b) 261.

${ }^{95}$ Jakab and Fröhlich (2017) 428.
} 
Understanding these factors can help to rebut the two major criticisms of the judicial use of comparative law: its legitimacy and methodology. Legitimacy criticisms, at least those appearing in court decisions and legal scholarship, had historically not garnered a great deal of attention in Hungary, but their recent resurgence has forced the Court to rethink its relationship with comparative reasoning. The methodological critics have had even louder voices and have urged the Court to take steps towards a more transparent and predictable reasoning practice. I agree with Szente that it would be an exaggeration to require the Court to establish such a coherent theory but, in the absence of it, there is no safeguard to defend judges from the selective or prejudiced citation of foreign law. ${ }^{, 96}$

There is indeed room for improvement, which could be realized with the use of multifaceted tools, which could in turn boost the legitimacy of comparative reasoning. Second, the methodology must not only be consistent; it must also be transparent. One of the characteristics of open justice is the expectation that courts are operating in legal, predictable and transparent ways. The concept of open justice also requires clear and transparent reasoning methods that help the public understand and accept the authority of a decision. Third, the work of justices and law clerks could be supported and improved by organizational, administrative and technological means. A separate court department dedicated exclusively to comparative questions, the availability of more translations and expanded online contact with fellow foreign courts are just a few examples of these recommended tools.

Legal scholarship has a crucial role to play in ameliorating the judicial practice of comparative reasoning. First, creating methodological templates, if realistic and user-friendly, can help judges in their everyday work. ${ }^{97}$ Second, most of the interviewees referred to the fact that they consulted journal articles and textbooks to understand foreign law, so more contributions to the genre of comparative constitutional law scholarship would be a great help. Finally, this paper provided only a short foray into the subject, but it has paved the way for further research in the field. These next steps should include a closer analysis of each citation of foreign law appearing in the Constitutional Court's opinions, a detailed presentation of the goals and results of the comparison (along with any inconsistencies, mistakes or misuses) and a comprehensive analysis of available preparatory documents, including briefs and case files.

\section{LITERATURE}

Annus, T., 'Comparative Constitutional Reasoning: The Law and Strategy of Selecting the Right Arguments' (2004) 14 Duke Journal of Comparative and International Law 301-49.

Bodnár, E., 'The Invisible Factors Behind Using Comparative Law in Constitutional Adjudication' (2019) 1 Romanian Journal of Comparative Law 201-26.

Bodnár, E., 'Az összehasonlító jog szerepe az Alkotmánybíróság családjogi ügyekkel kapcsolatos gyakorlatában' (The role of comparative law in the family-law jurisprudence of the Constitutional Court) in Szeibert, O. (ed), Gyermekek, fiatalkorúak, idöskorúak és a család (Eötvös Kiadó, 2020).

\footnotetext{
${ }^{96}$ Szente (2013b) 270-71.

${ }^{97}$ This is the aim of my project, 'The use of comparative law in constitutional adjudication', financed by the Premium postdoctoral grant of the Hungarian Academy of Sciences.
} 
Dupré, C., Importing the Law in Post-Communist Transitions. The Hungarian Constitutional Court and the Right to Human Dignity (Hart Publishing, 2003).

Groppi, T. and Ponthoreau, M.-C., 'Introduction. The Methodology of the Research: How to Assess the

Reality of Transjudicial Communication?' in Groppi, T. and Ponthoreau, M.-C. (eds), The Use of Foreign Precedents by Constitutional Judges (Hart Publishing, 2013) 1-10.

Halmai, G., 'Az aktivizmus vége. A Sólyom-bíróság 9 éve' (The end of activism: The 9 years of the Sólyom Court) (1999) 2 Fundamentum 5-27.

Harmathy, A., 'Changes in the Legal System: A Comparative Essay Based on the Hungarian Experience' (2019) 2 Journal of Civil Law Studies 217-52.

Jackson, V. C. and Tushnet, M., Comparative Constitutional Law (St. Paul: Foundation Press, 1999).

Jakab, A. and Fröhlich, J., 'The Constitutional Court of Hungary' in Jakab, A. and others (eds), Comparative

Constitutional Reasoning (Cambridge University Press, 2017) 394-437.

Kis, J. and Sajó, A., 'Amicus curiae az Alkotmánybírósághoz' (Amicus curiae to the Constitutional Court)

(2003) 1 Fundamentum 134-41.

Mak, E., Judicial Decision-Making in a Globalised World (Hart Publishing, 2015).

Rosenfeld, M., 'Comparative Constitutional Analysis in United States Adjudication and Scholarship' in

Rosenfeld, M. and Sajó, A. (eds), The Oxford Handbook of Comparative Constitutional Law (Oxford University Press, 2012) 38-52.

Roy, B., 'An Empirical Survey of Foreign Jurisprudence and International Instruments in Charter Litigation' (2004) 62 University of Toronto Faculty of Law Review 99-148.

Saunders, Ch., 'The Use and Misuse of Comparative Constitutional Law' (2006) 13 Indiana Journal of Global Legal Studies 37-76.

Saunders, Ch., 'Judicial Engagement with Comparative Law', in Ginsburg, T and Dixon, R (eds.), Comparative Constitutional Law (Edward Elgar, 2011) 571-98.

Sereg, A., Alkotmánybírák talár nélkül (Constitutional Justices without Robes) (KJK Kerszöv) 2005.

Slaughter, A.-M., 'A Typology of Transjudicial Communication' (1994) 29 University of Richmond Law Review 99-138.

Sonnevend, P., Jakab, A. and Csink, L., 'The Constitution as an Instrument of Everyday Party Politics: The Basic Law of Hungary' in Bogdandy, A. and Sonnevend, P. (eds), Constitutional Crisis in the European Constitutional Area. Theory, Law and Politics in Hungary and Romania (Hart Publishing, 2015) 33-110.

Szente, Z., 'A nemzetközi és külföldi bíróságok ítéleteinek felhasználása a magyar Alkotmánybíróság gyakorlatában 1999-2008 között' (The use of international and foreign judicial preedents in the jurisprudence of the Hungarian Constitutional Court, 1999-2008) (2010) 2 Jog, Állam, Politika 47-72. Szente, Z., 'Az Alkotmánybíróság értelmezési gyakorlata 1990-2010' (Interpretive practice in the jurisprudence of the Constitutional Court, 1990-2010) in Deli, G. and Szoboszlay-Kiss, K. (eds), Tanulmányok a 70 éves Bihari Mihály tiszteletére (Universitas 2013a) 497-518.

Szente, Z., 'Hungary: Unsystematic and Incoherent Borrowing of Law. The Use of Foreign Judicial Precedents in the Jurisprudence of the Constitutional Court, 1999-2010' in Groppi, T. and Ponthoreau, M.-C. The Use of Foreign Precedents by Constitutional Judges (Hart Publishing, 2013b) 253-72.

Open Access. This is an open-access article distributed under the terms of the Creative Commons Attribution 4.0 International License (https://creativecommons.org/licenses/by/4.0/), which permits unrestricted use, distribution, and reproduction in any medium, provided the original author and source are credited, a link to the CC License is provided, and changes - if any - are indicated. (SID_1) 